\title{
Structural and Functional Characteristics of Zoobenthos in the Lakes Located in Natural and Urbanistic Landscapes in Northwest Region of Russia
}

\author{
Victor P. Belyakov* and Alexandra I. Bazhora \\ Institute of Limnology RAS \\ 9 Sevastyanova Str., St.-Petersburg, 196105, Russia
}

Received 21.03.2016, received in revised form 03.05.2016, accepted 11.10.2016

\begin{abstract}
Structural and functional characteristics of zoobenthos in two lakes with different trophic status and the level of human impact were investigated in spring, summer and autumn 2013 and 2014. Species composition, degree of dominance, trophic structure, production and a role in the decomposition of organic matter were studied in zoobenthos of the two lakes. Seasonal dynamics of the quantitative characteristics of zoobenthos in lakes with varying anthropogenic impact showed an asynchronous response of the communities on dynamics of natural factors.
\end{abstract}

Keywords: zoobenthos, lakes, community structure, production, bioindication, anthropogenic impact, northwest of Russia.

DOI: $10.17516 / 1997-1389-2016-9-4-484-498$.

(C) Siberian Federal University. All rights reserved

* Corresponding author E-mail address: victor_beliakov@mail.ru 


\title{
Структурно-функциональные характеристики зообентоса озер, расположенных в природных \\ и урбанистических ландшафтах \\ Северо-Западного региона России
}

\author{
В.П. Беляков, А.И. Бажора \\ Институт озероведения РАН
}

Россия, 196105, Санкт-Петербург, ул. Севастьянова, 9

Структурно-функичональные характеристики зообентоса двух озер с разным уровнем трофии и степени антропогенного воздействия на их экосистемы были исследованы весной, летом и осенью 2013 и 2014 г2. Отмечень особенности видового состава, степени доминирования, трофической структуры, продукции сообщества зообентоса и его участия в деструкции органических веществ в озерах. Сезонная динамика количественных характеристик зообентоса озер с разной антропогенной нагрузкой демонстрировала несинхронность отклика сообщества на действие природных факторов.

Ключевые слова: зообентос, озера, структура сообществ, продукция, биоиндикация, антропогенное воздействие, Северо-Запад России.

\section{Введение}

В регионах с высокой плотностью населения, значительной транспортной сетью, развитыми промышленностью и сельским хозяйством водные экосистемы находятся в критическом состоянии. В озерных экосистемах таких районов нарушен ход естественной сукцессии, происходят необратимые перестройки биологических сообществ и деградация механизмов поддержания их энергетического баланса. Поэтому среди задач, которые поставлены перед лимнологами, стоит не только оценка современного экологического статуса водоемов, но и получение структурнофункциональных характеристик их биологических сообществ с целью определения возможностей самоочищения. В загрязненных водоемах, где почти отсутствует рыбное население, зообентос часто является завершающим звеном трофических цепей и акку- мулирует значительную часть загрязнений. Это обстоятельство, как и более длительный по сравнению с планктоном жизненный цикл обитателей дна, делает зообентос хорошим индикатором экологического состояния озер. Его функциональные показатели иллюстрируют участие сообщества в трансформации вещества и энергии в экосистеме при различных антропогенных нагрузках (Алимов и др., 1979; Слепухина, 1987; Johnson, 1995; Шитиков и др., 2005 и др.).

При антропогенном эвтрофировании озер, расположенных на территориях с развитой сельскохозяйственной деятельностью или рекреацией, в них отмечается увеличение количественных показателей зообентоса и структурная перестройка сообщества, связанная с изменением основных трофических потоков (Wisniewski, Dusoge, 1983; Алимов, 1991; Беляков, 1992). В случае промышлен- 


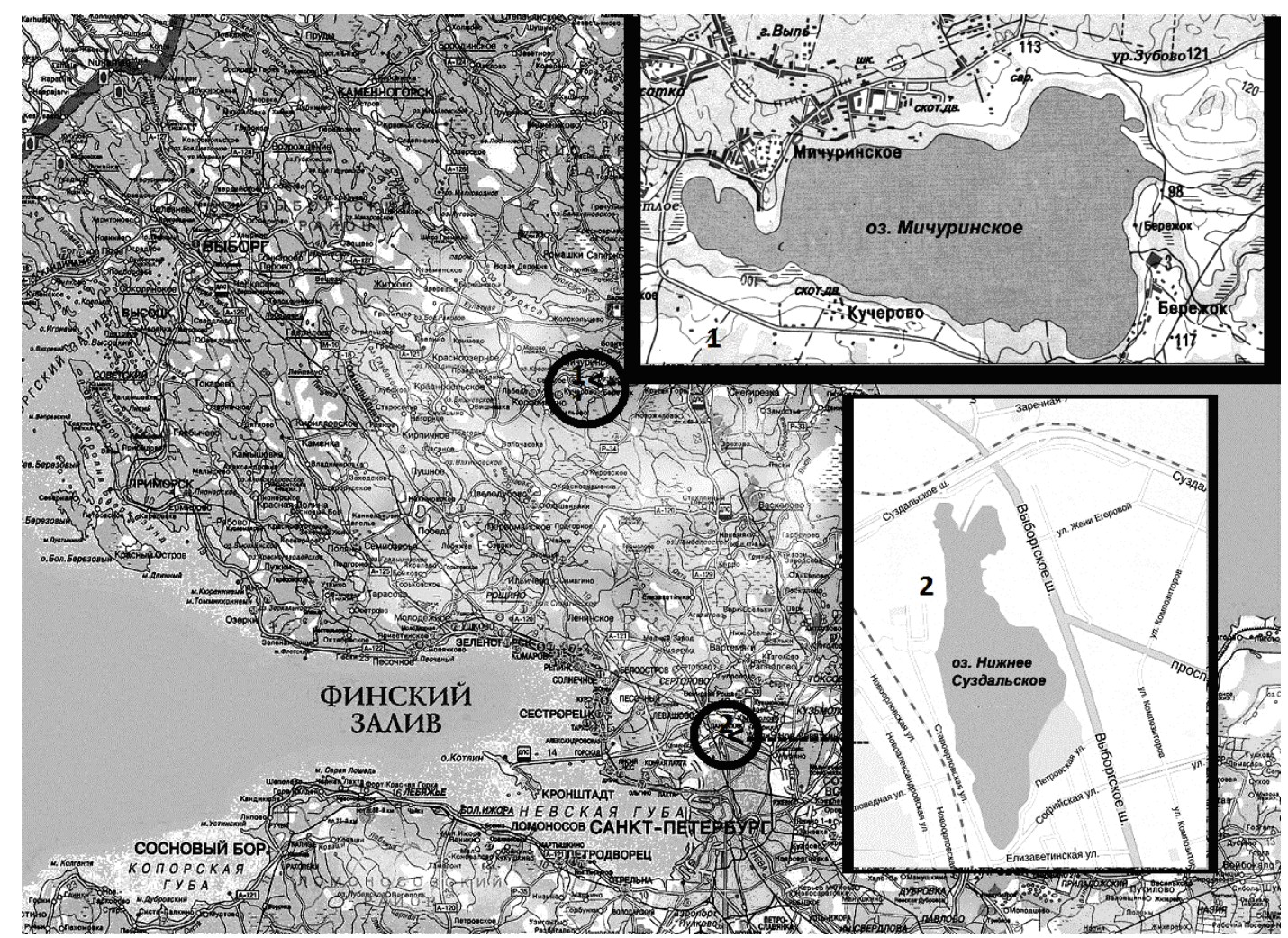

Рис. 1. Карта-схема расположения исследованных озер

ных, токсичных загрязнений изменения сообществ носят сложный характер, трудно поддающийся интерпретации, что объясняется тем, что к множеству существующих природных факторов добавляются антропогенные факторы, действующие прямо и опосредованно, как синергично, так и разнонаправленно (Яковлев, 2005).

Целью работы было исследование состава, структуры и продуктивности макрозообентоса двух озер ледникового происхождения, расположенных в камовоозерно-ледниковом ландшафте Карельского перешейка (рис. 1).

\section{Материалы и методы}

Озеро Нижнее Суздальское (60³'19" с.ш., $30^{\circ} 18^{\prime} 1^{\prime \prime}$ в.д., площадь 0,75 км², максимальная глубина 5,5 м, средняя - 2,5 м) - часть водной системы, разгружающейся в Лахтинский разлив Финского залива, 80 \% водосбора (общая площадь 35,5 км²) которой занимают земли, занятые сельскохозяйственными, промышленными и городскими территориями. Максимальная антропогенная нагрузка отмечается вокруг озера и в устье впадающей в него p. Старожиловки. Действие антропогенных факторов проявляется в превышении ПДК по содержанию нефтепродуктов, тяжелых металлов и органических веществ (Водные объекты, 2002).

Озеро Мичуринское (площадь 5,8 км², максимальная глубина 16 м, средняя глубина 8 м), которое расположено на северозападном склоне Центральной Карельской возвышенности (60³3'25" с.ш., 2953'18" в.д.), подвергается менее интенсивному антропогенному воздействию, поскольку име- 
Таблица 1. Некоторые гидрохимические характеристики исследованных озер (над чертой - минимальные значения, под чертой - максимальные)*

\begin{tabular}{|c|c|c|c|c|c|c|c|}
\hline Водоем & $\begin{array}{c}\text { Сумма } \\
\text { ионов, мг/л }\end{array}$ & $\mathrm{pH}$ & $\begin{array}{l}\text { Цвет- } \\
\text { ность }\end{array}$ & $\begin{array}{c}\text { Содержание } \\
\text { кислорода, мг/л } \\
\text { (\% насыщения) }\end{array}$ & $\begin{array}{l}\text { ХПК, } \\
\text { мгО/л }\end{array}$ & $\begin{array}{l}\text { БПК } \\
\text { мгО/л }\end{array}$ & $\begin{array}{c}\text { Содержание } \\
\text { общего } \\
\text { фосфора, мкгР/л }\end{array}$ \\
\hline \multirow{2}{*}{ оз. Мичуринское } & $\underline{44}$ & $\underline{6,86}$ & $\underline{20}$ & $\underline{2,16(21 \%)}$ & 10,80 & $\underline{0,67}$ & $\underline{0,017}$ \\
\hline & 50 & 8,38 & 32 & $10,79(94 \%)$ & 23,90 & 3,09 & 0,034 \\
\hline оз. Нижнее & 197 & 6,90 & $\underline{32}$ & $\underline{0,44}(5 \%)$ & $\underline{55,80}$ & 4,95 & $\underline{0,199}$ \\
\hline Суздальское & $\overline{354}$ & $\overline{8,57}$ & $\overline{34}$ & $11,49(105 \%)$ & $\overline{65,60}$ & $\overline{6,28}$ & 0,232 \\
\hline
\end{tabular}

*Примечание: по данным Н.В. Игнатьевой (2014).

ет значительно меньшее отношение площади водосбора к объему озера (водосбор

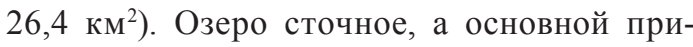
ток обеспечивается за счет грунтовых вод и осадков, нет существенных водотоков, впадающих в водоем. Небольшие загрязнения поступают со склоновым стоком от пос. Мичуринского, также отмечается влияние рекреации. Воздействие сельского хозяйства в настоящее время минимально (Трифонова, 1979).

Несмотря на общность происхождения, в озерах наблюдаются заметные различия гидрохимических характеристик (табл. 1), в частности в оз. Н. Суздальском к обычному для данного района преобладанию в воде ионов карбонатно-кальциевой группы добавляются хлоридные и даже сульфатные ионы (Игнатьева, 2014). В период открытой воды в профундали оз. Мичуринского не было дефицита кислорода, а в более мелком оз. Н. Суздальском он был отмечен в отдельные сроки. Следствием антропогенной нагрузки являются также повышенные концентрации в воде и донных отложениях этого озера нитритов, свинца, меди и никеля. Высокие значения БПК 5 связаны не только с образованием легкоокисляемых автохтонных форм органических веществ, но и со смывом с городской территории (Водные объекты, 2002; Игнатьева, 2014).
Пробы зообентоса отбирали в мае, июле и сентябре 2013-2014 гг. на фиксированных станциях основных биотопов озер в центральной и литоральной зоне. Использовали стандартные методы сбора и обработки зообентоса (Методические рекомендации, 1983), продукционные показатели определяли физиологическим методом (Винберг, Беляцкая, 1959; Камлюк, 1974; Алимов, 1981; Балушкина, 1987 и др.). При определении видового состава методы кариологического анализа не использовали. Хирономиды определяли по двум, а в некоторых случаях по трем стадиям развития (личинка, куколка, имаго). Индекс сапробности по Пантле и Букк определяли в модификации Сладечека (Sladecek, 1973).

\section{Результаты}

В результате проведенных исследований было обнаружено 82 вида и формы донных беспозвоночных, большинство из них (53) хирономиды, которые часто преобладали и количественно. Довольно высокий коэффициент сходства Съеренсена $\left(\mathrm{K}_{\mathrm{S}}\right)$ списков донной фауны двух озер равен 0,45 , что объясняется одинаковыми базовыми условиями формирования сообществ.

В профундальной зоне обоих озер попеременно доминируют личинки Chironomus gr. plumosus и Chaoborus crystallinus (De Geer). Кроме них, в оз. Нижнем Суздальском были 


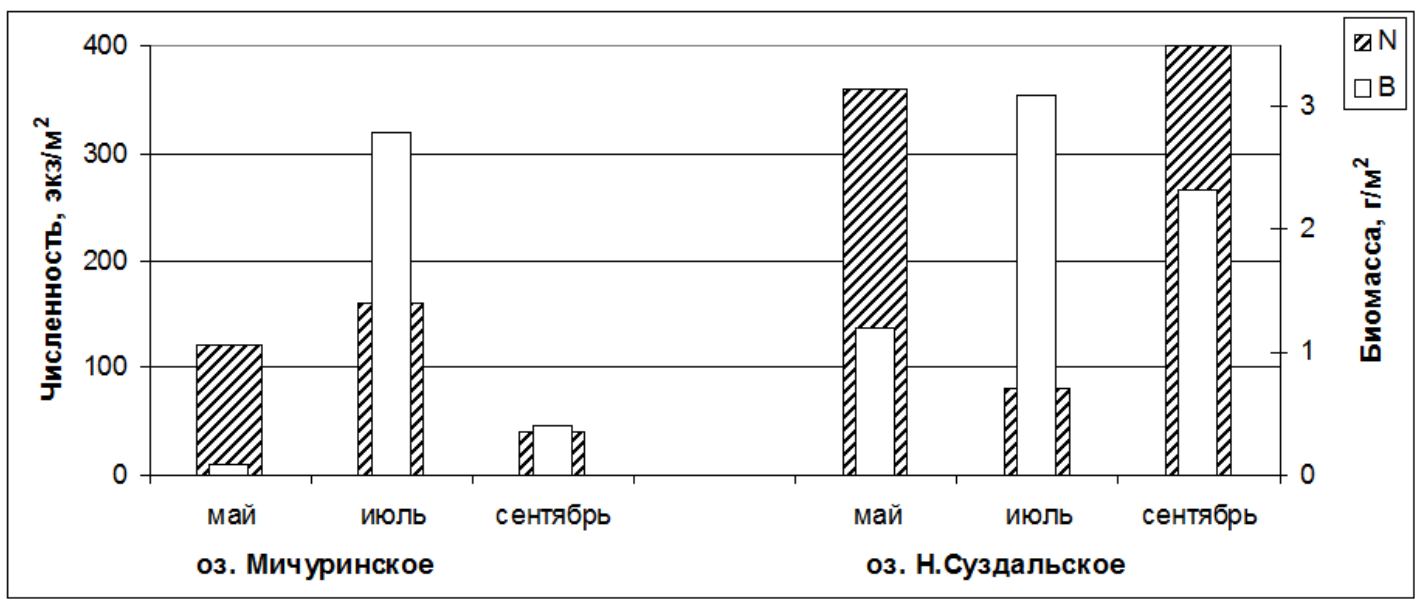

Рис. 2. Изменение численности (N) и биомассы (B) макрозообентоса в профундали озер Мичуринское и Нижнее Суздальское в 2014 г.

встречены олигохеты Limnodrilus hoffmeisteri Claparede и еще два малозначимых вида, а в оз. Мичуринском - 10 видов. В биотопе илов исследованных озер количественно преобладали полисапробы, поэтому и индекс сапробности соответствовал $\alpha$-мезосапробной зоне 2,82-3,24. В течение периода открытой воды суммарные количественные показатели зообентоса профундали демонстрировали разную динамику в двух озерах (рис. 2). Это связано с тем, что в оз. Н. Суздальском в июле отмечен дефицит кислорода у дна. В результате исчезли все популяции, кроме набирающих массу личинок C. plumosus. В дальнейшем, в сентябре, отмечен частичный вылет имаго этой популяции, а общая численность зообентоса росла за счет субдоминантов C. crystallinus и L. hoffmeisteri. В оз. Мичуринском максимальные значения численности и биомассы зообентоса профундали отмечены в июле (рис. 2), что определялось наличием свежей пищи - автохтонной органики, поступившей на дно после весеннего пика развития водорослей.

Трофическая структура сообщества 3о0бентоса профундали двух озер, несмотря на сходный видовой состав, заметно отличается как по вкладу отдельных трофических группировок в общую биомассу, так и в участии этих групп в деструкции органического вещества зообентосом (рис. 3). В эвтрофном оз. Н. Суздальском заметна доля группировки хищников, которые удовлетворяют свои пищевые потребности, питаясь зоопланктоном. Значение неизбирательных детритофаговглотателей тоже выше, чем в мезотрофном оз. Мичуринском.

Следующий тип биотопа в обоих озерах объединяет не только небольшая глубина (до 2 м) и илистый грубодетритный грунт, но и наличие зарослей высших водных растений. Причем в оз. Н. Суздальском биотоп занимал территорию полностью зарастающего залива, куда впадала р. Старожиловка - основной источник загрязнения. Видовое разнообразие зообентоса там выше, чем в профундали (число видов до 9, индекс Шеннона 1,25-3,01 бит/ экз), но доминировали тоже полисапробы L. hoffmeisteri и C. plumosus. Индекс сапробности по зообентосу составлял от 3,24 до 3,60. Разнообразие и количественные показатели донного сообщества в этом биотопе снижа- 


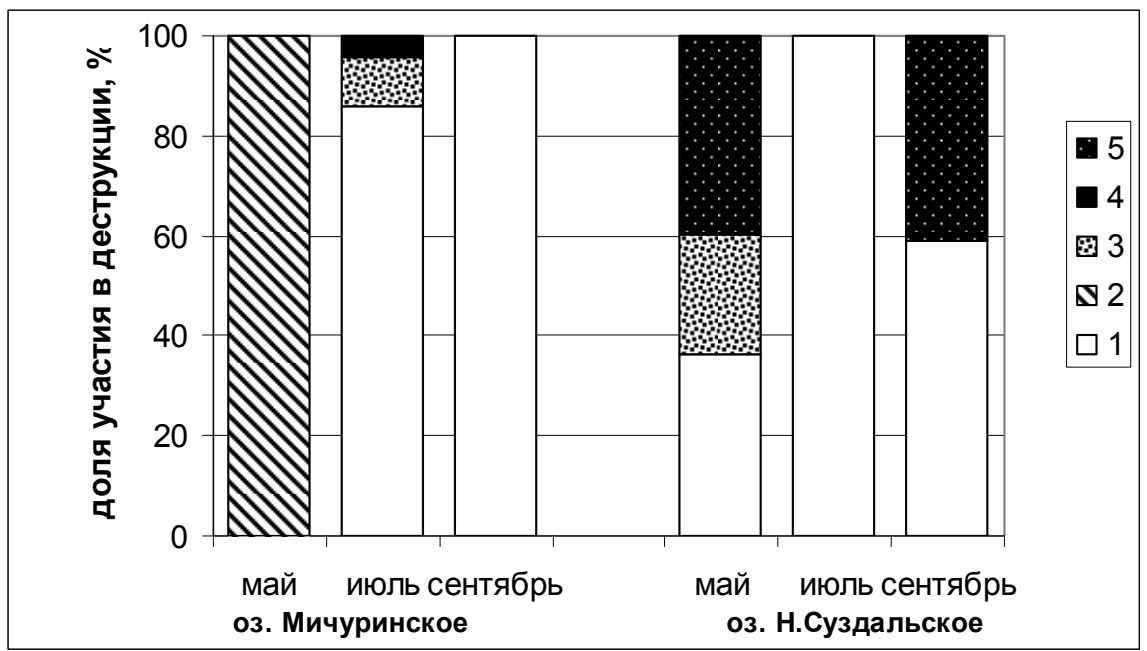

Рис. 3. Участие трофических групп макрозообентоса в деструкции органического вещества в профундали двух озер в 2014 г.: 1 - фитодетритофаги-фильтраторы+собиратели; 2 - детритофаги-собиратели; 3 - безвыборочные детритофаги-глотатели; 4 - хищники; 5 - хищники в зоопланктоне

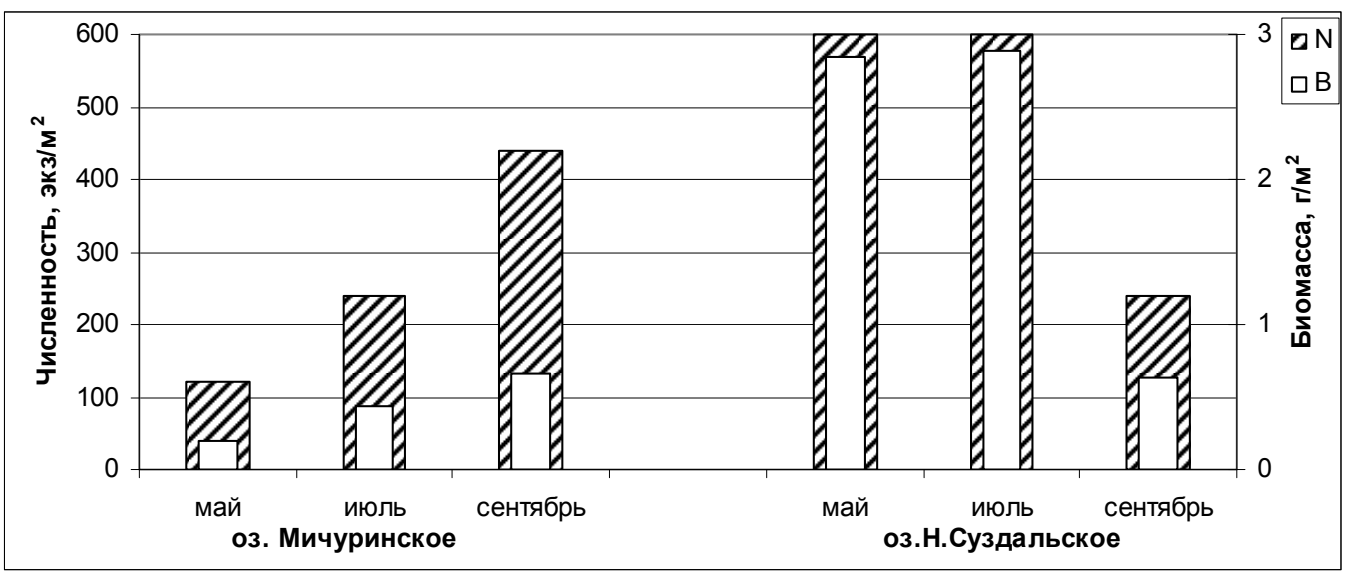

Рис. 4. Изменение численности и биомассы макрозообентоса в заросших заливах озер Мичуринское и Нижнее Суздальское в 2014 г.

лись к осени, с началом отмирания растительности. В аналогичном биотопе оз. Мичуринского к осени отмечался рост показателей (рис. 4), доминировали личинки Einfeldia carbonaria (Meigen) и сем. Ceratopogonidae, видовое разнообразие было не выше 1,87 бит/экз, число видов незначительно - до 5, в основном присутствовали $\beta$-мезосапробы. Различия трофической структуры макрозообентоса в этой зоне двух озер еще заметнее, чем в про- фундали, - с ростом уровня трофии снижается доля хищников, фильтраторов и собирателей фитодетритофагов, и растет вклад детритофагов-глотателей (рис. 5). Несмотря на значительное развитие макрофитов, в заросшем заливе оз. Н. Суздальского фитофаги в бентосе практически незаметны, возможно, из-за низких концентраций содержания кислорода у дна. Тогда как в оз. Мичуринском в сентябре полуразложившиеся макрофиты 


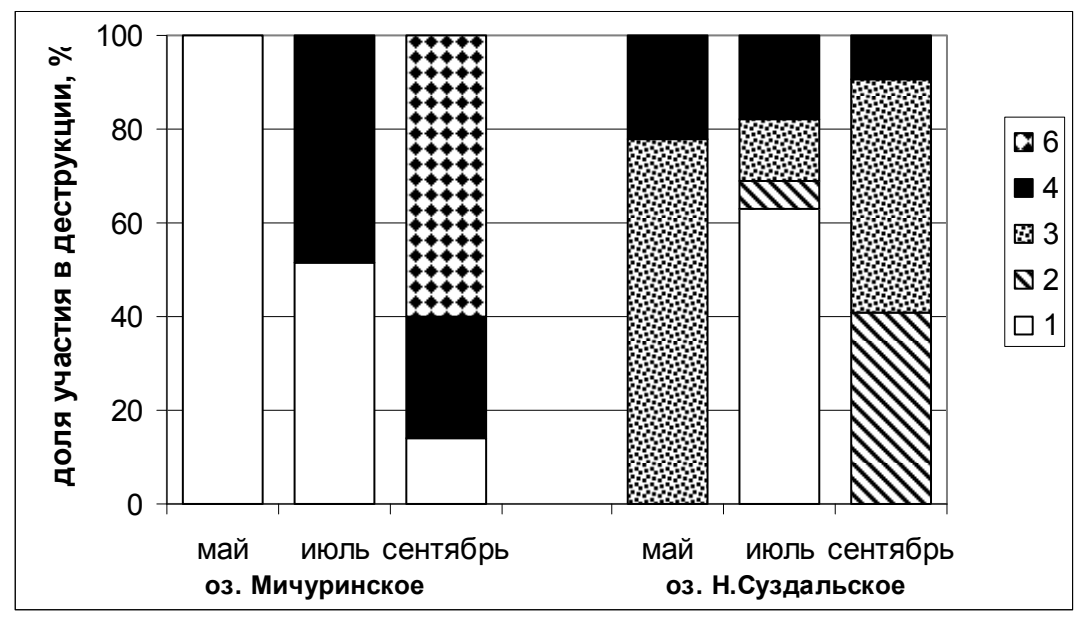

Рис. 5. Участие трофических групп макрозообентоса в деструкции органического вещества в зарастающих заливах двух озер в 2014 г. 6 - макрофитофаги, остальные обозначения как на рис. 3

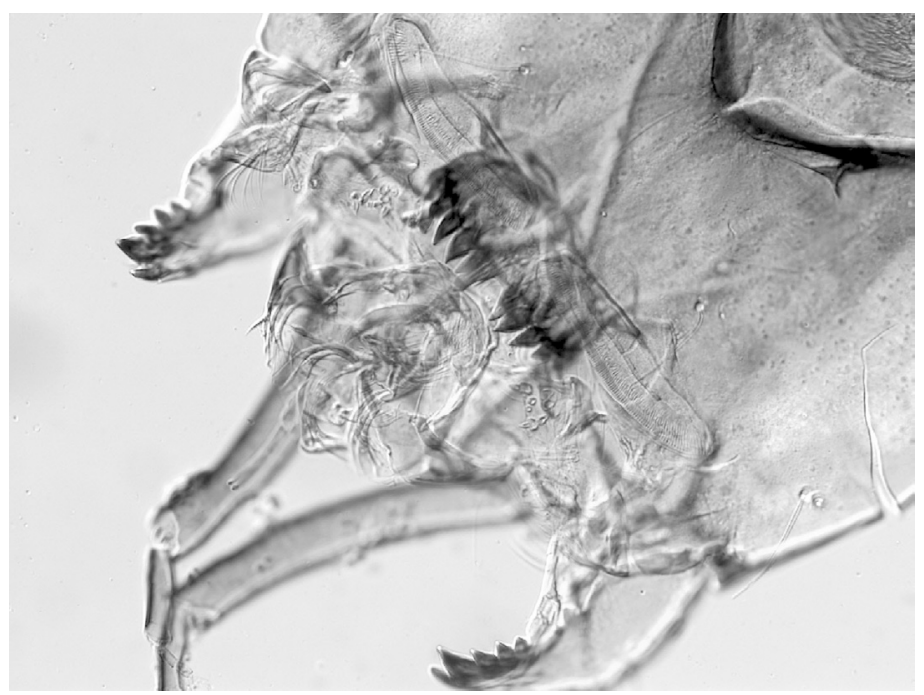

Рис. 6. Головная капсула личинки Tanytarsus sp. с морфологическими нарушениями субментума из заросшего залива оз. Нижнего Суздальского в 2014 г.

становятся доступнее для фитофагов, а дефицита кислорода нет.

Для загрязненного залива оз. Н. Суздальского отмечен высокий процент встречаемости (до 25-35 \%) особей с морфологическими отклонениями, в частности личинок хирономид, особенно среди группы детритофаговсобирателей (Беляков, Сотников, 2014) (рис. 6). Возможно, в связи с высоким процен- том уродств среди донных беспозвоночных в этом биотопе имело место снижение обилия доминантов, хотя прямой связи между ростом смертности и процентом уродств выявлено не было.

Основной биотоп литорали оз. Мичуринского - слабозаиленный песчаный, с редкими пятнами высшей водной растительности. Целый ряд видов доминирует по численно- 


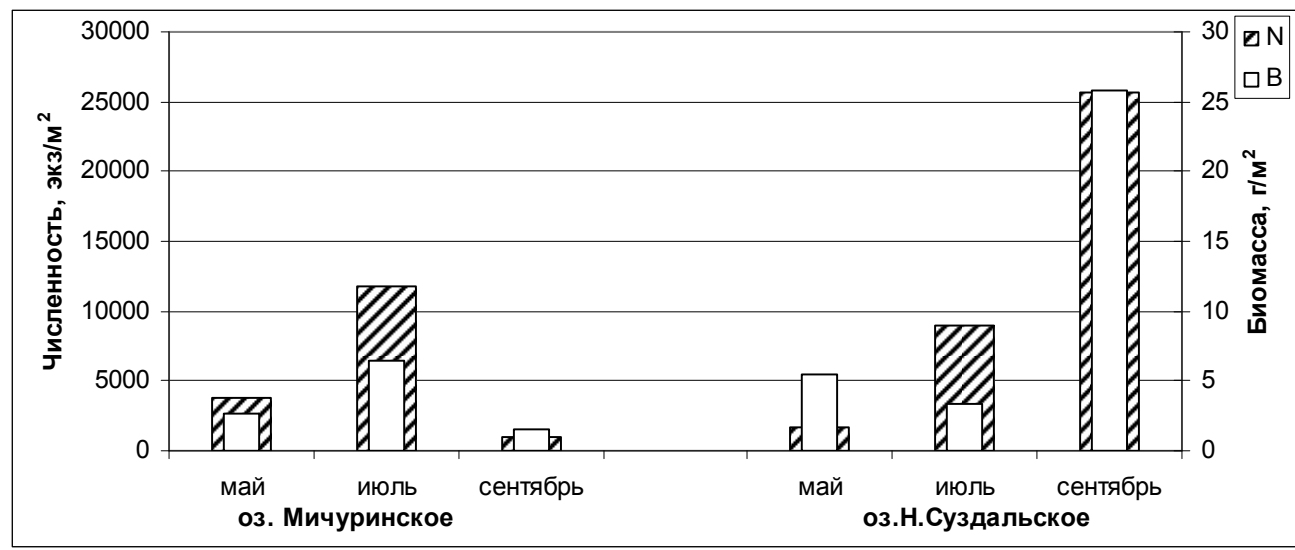

Рис. 7. Изменение численности (N) и биомассы (B) макрозообентоса на литорали озер Мичуринское и Нижнее Суздальское в 2014 г.

сти и биомассе в разные сроки: Nais barbata O. F. Müller, Cladotanytarsus mancus (Walker), Stictochironomus crassiforceps (Kieffer), Cricotopus silvestris (Fabricius), особенно заметен значительно увеличивший свою плотность вселенец - Gmelinoides fasciatus Stebbing. Cpeди субдоминантов в зооценозе: C. plumosus, Glyptotendipes paripes Edwards, Endochironomus albipennis Meigen, Synendotendipes impar (Walker), Polypedilum tetracrenatum Hirvenoja, моллюски Euglesa sp., а также личинки Cеratopogonidae. На литорали озера качество воды соответствовало $\beta$-мезосапробной зоне (1,73-1,93). Общие количественные показатели зообентоса литорали оз. Мичуринского в оба года наблюдений достигали максимальных величин в июле (рис. 7). Причем если по биомассе главным образом за счет популяции G. fasciatus, то по численности в 2014 г. в этот месяц преобладали олигохеты. В целом на протяжении двух лет на литорали озера сохранялась стабильная структура зооценоза с общим доминированием G. fasciatus и практически одинаковой сменой субдоминантов в течение вегетационного сезона. Тем не менее средние за сезон показатели численности и биомассы литорального зообентоса оз. Мичу- ринского существенно различались в разные годы, соответственно в 2014 г. - 5500 экз/м² и 3,54 г/м² были заметно выше, чем в 2013 г. -

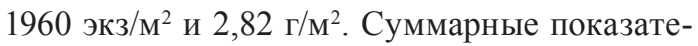
ли зообентоса на литорали отражают увеличение к осени численности беспозвоночных с большими максимальными конечными массами, т.е. преобладание популяций с более длительным циклом развития.

На литорали оз. Нижнего Суздальского в разные сроки доминировали олигохеты Limbriculus variegatus O. F. Müller, L. hoffmeisteri, личинки хирономид E. albipennis и моллюски Planorbarius corneus (Linnaeus), в числе субдоминантов здесь выступают доминирующие на литорали другого озера личинки C. mancus, $S$. crassiforceps и C. silvestris, а также Glyptotendipes glaucus (Meigen), Dicrotendipes nervosus (Staeger) и Larsia sp. Ход изменения общих количественных показателей зообентоса здесь отличался в разные годы: если в 2013 г. максимальное значение биомассы было отмечено в мае (до 58,2 г/M²), а численности (около 20 тыс. экз/ м $^{2}$ ) в сентябре, а в июле был спад обеих величин, то в 2014 г. численность росла к осени и спад в июле не отмечен (рис. 7). Общим для этих лет 


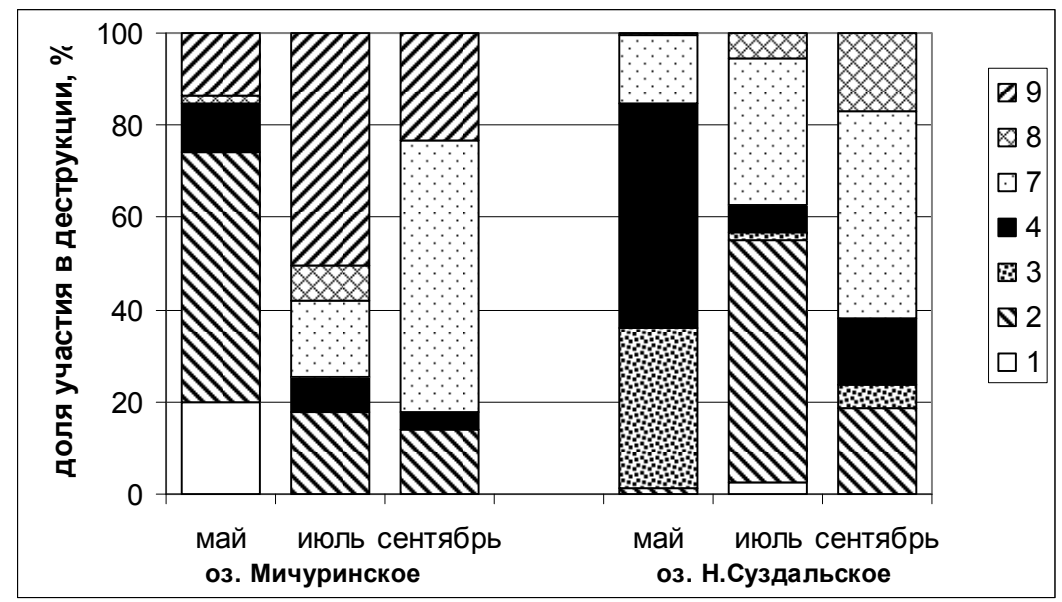

Рис. 8. Участие трофических групп макрозообентоса в деструкции органического вещества на литорали двух озер в 2014 г.: 7 - фитодетритофаги-фильтраторы; 8 - перифитонофаги-соскребатели; 9 - всеядные (хищники+детритособиратели), остальные обозначения как на рис. 3

было преобладание весной более крупных организмов, как правило гастропод, которые поедали свежие обрастания и накопившийся осенью и не разложившийся за зиму детрит. Детрит весной, возможно, был менее токсичен, поскольку концентрация нефтепродуктов в донных отложениях весной $\left(0,064\right.$ мг л $\left.{ }^{-1}\right)$ была ниже, чем летом и осенью: 0,258 и 0,380 мг л ${ }^{-1}$ соответственно (Игнатьева, 2014).

Трофическая структура зооценозов макрозообентоса литорали двух озер заметно отличается, различен и ход ее сезонных изменений (рис. 8). В мезотрофном оз. Мичуринском роль детритофагов-собирателей еще заметна весной, но летом и осенью их нишу занимают всеядные организмы, возможно, за счет замещения ими и функции хищников. Летом и особенно в сентябре заметна роль фильтраторов. В эвтрофном оз. Н. Суздальское литораль более заиленная - отсюда весной выше значение неизбирательных детритофагов-глотателей. Весенний пик развития фитопланктона способствует развитию фильтраторов в бентосе, которые увеличивают свое участие в трансформации органических веществ к осени. В середине лета замет- нее детритофаги-собиратели, а к сентябрю представлены почти все трофические группы. Участие хищников на литорали озера значимо только в мае, соответственно, в этот период отношение суточной продукции ценоза к суммарной деструкции минимально $(0,29)$, в июле этот показатель был равен 0,83 , а в сентябре - 0,45. На литорали оз. Мичуринского показатель отношений суточных величин $\mathrm{P} / \mathrm{R}$ в течение сезона менялся иначе: в мае $-0,73$, в июле $-0,48$, в сентябре - 0,64. Среднесезонные показатели суточных $\mathrm{P} / \mathrm{R}$ сообщества на литорали двух озер различались незначительно, как и средневзвешенные для озера в целом, но для профундального зообентоса и для зооценозов зарастающих заливов отношение $\mathrm{P} / \mathrm{R}$ оказалось выше в более эвтрофном оз. Н. Суздальском (табл. 2).

Для сообществ макрозообентоса двух озер были рассчитаны приблизительные значения их продукции, деструкции за сезон и среднесезонные биомассы (табл. 2). О существенных структурных различиях сообществ говорят заметно более высокие отношения сезонной деструкции и среднесезонной биомассы (R/B сез.) в мезотрофном озере, чем в 
Таблица 2. Средние за 2013-2014 гг. функциональные и структурные показатели зообентоса исследованных озер для периода открытой воды

\begin{tabular}{|c|c|c|c|c|c|c|}
\hline Зоны & $\mathrm{B}$ & $\mathrm{P}$ & $\mathrm{R}$ & $\mathrm{P} / \mathrm{R}$ сут & R/B сез. & Н, бит/экз \\
\hline \multicolumn{7}{|c|}{ оз. Мичуринское } \\
\hline Профундаль & 0,08 & 0,17 & 0,23 & 0,74 & 2,88 & 1,03 \\
\hline $\begin{array}{l}\text { Заросший } \\
\text { залив }\end{array}$ & 0,03 & 0,07 & 0,20 & 0,35 & 6,67 & 1,66 \\
\hline Литораль & 0,28 & 0,88 & 1,93 & 0,46 & 6,89 & 2,30 \\
\hline Все озеро & 0,11 & 0,30 & 0,57 & 0,53 & 5,03 & \\
\hline \multicolumn{7}{|c|}{ оз. Нижнее Суздальское } \\
\hline Профундаль & 0,13 & 0,34 & 0,43 & 0,79 & 3,27 & 0,79 \\
\hline $\begin{array}{l}\text { Заросший } \\
\text { залив }\end{array}$ & 0,13 & 0,23 & 0,53 & 0,43 & 4,15 & 2,16 \\
\hline Литораль & 0,69 & 1,31 & 3,13 & 0,42 & 4,54 & 2,55 \\
\hline Все озеро & 0,19 & 0,41 & 0,73 & 0,56 & 3,90 & \\
\hline
\end{tabular}

Примечание: В - биомасса, Р - продукция, R - деструкция (в гС/м² сезон); Н - индекс видового разнообразия Шеннона.

эвтрофном. С увеличением уровня трофии, хотя и не настолько, как ожидалось, отмечается рост абсолютных значений биомасс, продукции и деструкции, тогда как такой структурный показатель, как индекс видового разнообразия Шеннона, ниже только в профундали.

\section{Обсуждение}

Основными факторами, которые действуют на состав, структуру и количественные показатели макрозообентоса, являются гидрологические и химические характеристики, температурный и газовый режим, характеристики грунта, наличие водной растительности, уровень трофности и загрязнение водоема (Яковлев, 2005; Безматерных, 2007).

В оз. Н. Суздальском часть исходных природных характеристик была, как и во многих других озерах региона, изменена в результате антропогенной деятельности. В частности, изменились: состав ионов, концентрация кислорода у дна, степень заиления литорали, интенсивность зарастания макрофитами, уровень трофии, концентрация ток- сикантов в донных отложениях и пищевых цепях (Кузьменко, 1964; Трифонова, 1979; Игнатьева, 2014). Еще одним действующим фактором может быть небольшое повышение температурного фона в условиях города. Вероятно, все факторы, кроме ионного состава воды и температурного фона, заметно сказались на составе, структуре и количественных показателях макрозообентоса: выпадение оксифилов, преобладание пелофилов на литорали, высокие биомассы, морфологические отклонения у беспозвоночных и т.п.

Озеро Мичуринское подвергается меньшей антропогенной нагрузке, приводящей к эвтрофированию, а также произошла инвазия чужеродного вида. Более низкий показатель разнообразия сообщества на литорали озера объясняется значительным развитием и доминированием вселенца G. fasciatus. Его популяция сыграла роль фактора дестабилизации, нарушив ход изменений сообщества при повышении трофического уровня, обычно проявляющегося в постепенном снижении роли хищников и повышении продукции зооценоза. Эти рачки повысили общие коли- 
чественные показатели зообентоса, заместив хищников за счет своей всеядности и снизив тем самым долю мелких детритофагов, аналогично тому, как это происходит в литоральной зоне Ладожского озера (Курашов и др., 2006).

Морфологические различия озер и их гидрологический режим не привели к существенным расхождениям состава донных беспозвоночных. В фаунистических списках обоих озер выделяется сходное ядро эврибионтных видов, встречающихся в большинстве озер Карельского перешейка (Беляков, 2008). Сукцессии экосистем обоих озер в результате антропогенного эвтрофирования не вызывали полного исчезновения характерной реликтовой фауны, которая отмечалась в озерах региона еще в 40-50-е гг. прошлого века (Кузьменко, 1964). В настоящее время разница в степени и видах антропогенной нагрузки на исследованные озера привела к изменению структуры доминирования и смене доминантов-субдоминантов. Различие в уровне трофии привело к изменению количественных показателей зообентоса, что многократно отмечалось в работах, посвященных последствиям антропогенного эвтрофирования или искусственного повышения кормности озер (Jonasson, 1969; Петров, 1971; Saether, 1980; Wiśniewski, Dusoge, 1983; Бeляков, 1992). Состав первичных продуцентов влияет на ход и форму трофических потоков, поступающих в донные зооценозы. Различие доминирующих форм в последних приводит к расхождению сезонной динамики суммарных показателей зообентоса. Функциональные показатели самого зообентоса (скорость роста, интенсивность обмена и т.п.) зависят не только от количества и вида пищи, но и от температурных, кислородных условий на дне, а также от присутствия отравляющих, ингибирующих или стимулирующих ве- ществ в биотопах. На эти показатели влияют также биотические отношения внутри 30оценозов или с другими зооценозами данной экосистемы (Голубков, 2000; Яковлев, 2000). Наличие токсической составляющей, повидимому, нарушает обычный ход изменения донных зооценозов при повышении уровня трофии озерных экосистем, что сказывается на функциональных характеристиках сообществ. Наиболее четко это проявляется в увеличении числа особей с морфологическими нарушениями, последнее обстоятельство достаточно широко отмечается в работах многих авторов (Warwick, 1985; Назарова, 2002; Яковлев, 2005; Беляков, Сотников, 2014 и др.). В оз. Н. Суздальском наличие уродств у бентосных детритофагов-собирателей, скорее всего, связано с накоплением в донных отложениях тяжелых металлов, в частности свинца (Водные объекты, 2002). Этим же, возможно, объясняется слабое развитие трофических групп при наличии соответствующего вида пищи в загрязненном заливе оз. Н. Суздальского.

\section{Заключение}

В результате проведенных исследований выявлено, что в озерах со сходными природными характеристиками при повышении уровня трофии озера снижается видовое богатство, повышается доля полисапробов, отмечается рост количественных показателей зообентоса. В зависимости от трофического статуса или при влиянии негативных факторов происходит замена доминантов, но, вне зависимости от этого статуса, в составе зообентоса формируется ядро толерантных, эврибионтных массовых видов. При действии различных антропогенных факторов наблюдается перестройка структуры сообщества, в том числе трофической, которая приводит к несинхронности в динамике суммарных количе- 
ственных показателей зообентоса. Выявлено, что функциональные показатели сообщества зообентоса, в частности его деструкционная активность, связаны со структурными и являются индикаторами состояния среды обитания. Расхождение наблюдаемых функциональных характеристик с ожидаемыми значениями, возможно, указывает на наличие сильных токсичных загрязнений. Это подтверждается обнаружением в загрязненном оз. Н. Суздальском донных беспозвоночных с морфологическими отклонениями, особенно часто встречающимися у представителей детритофагов, что говорит о накоплении токсикантов в детритной цепи. Полученные нами результаты расширяют представление о характере структурно-функциональных перестроек сообществ зообентоса не только в связи с ростом уровня трофии, но и при комплексном антропогенном загрязнении, включая токсичные, в водоемах урбанистического ландшафта.

\section{Список литературы}

Алимов А.Ф. (1981) Функииональная экология пресноводных двустворчатых моллюсков. Л., Наука, 248 с. [Alimov A.F. (1981) Functional ecology of freshwater Bivalves. Leningrad, Nauka, 248 p. (in Russian)]

Алимов А.Ф. (1991) Сезонные и многолетние изменения биомассы зообентоса континентальных водоемов. Гидробиологический журнал, 27 (2): 3-9 [Alimov A.F. (1991) Seasonal and perennial changes in the biomass of the zoobenthos of the continental water bodies. Hydrobiological Journal [Gidrobiologicheskii Zhurnal], 27 (2): 3-9 (in Russian)]

Алимов А.Ф., Бульон В.В., Гутальмахер Б.Л., Иванова И.Б. (1979) Применение биологических и экологических показателей для определения степени загрязнения природных вод. Водные ресурсы, 5: 137-150 [Alimov A.F., Bouillon V.V., Gutelmakher B.L., Ivanova I.B. (1979) Use of biological and ecological indicators to determine the degree of pollution of natural waters. Water Resources [Vodnie resursi], 5: 137-150 (in Russian)]

Балушкина Е.В. (1987) Функциональное значение личинок хирономид в континентальных водоемах. Л., Наука, 179 c. [Balushkina E.V. (1987) Functional role of chironomid larvae in continental reservoirs. Leningrad, Nauka, 179 p. (in Russian)]

Безматерных Д.М. (2007) Зообентос как индикатор экологического состояния водных экосистем Западной Сибири. Экология. Серия аналитических обзоров мировой литературы, 85: 1-87 [Bezmaternyh D.M. (2007) Zoobenthos as indicator of ecological state of aquatic ecosystems of Western Siberia. Ecology. A series of analytical surveys of world literature [Ehkologiya. Seriya analiticheskih obzorov mirovoj literatury], 85: 1-87 (in Russian)]

Беляков В.П. (1992) Структура и продуктивность сообществ макрозообентоса малых озер Латгальской возвышенности и их зависимость от экологических факторов. Автореф. дис. ... канд. биол. наук. Институт озероведения РАН, СПб., 23 с. [Belyakov V.P. (1992) The structure and productivity of macroinvertebrate communities of small lakes in the Latgale upland and their dependence on environmental factors. Author. dis. ... candidate. Biol. Sciences. Institute of Limnology RAS, St. Petersburg, 23 p. (in Russian)]

Беляков В.П. (2008) Многолетние изменения зообентоса. Многолетние изменения биологических сообществ мезотрофного озера в условиях климатических флуктуаций и эвтрофирования. Трифонова И.С. и др. (ред.) СПб., Лема, с. 167-184 [Belyakov V.P. (2008) Long-term changes

$$
-495-
$$


of zoobenthos. Long-term changes in biological communities mesotrophic lake under conditions of climatic fluctuations and eutrophication. Trifinova I.S. et al. (eds.) St. Petersburg, Lema, p. 167-184 (in Russian)]

Беляков В.П., Сотников И.В. (2014) Морфологические деформации личинок хирономид как показатель загрязненности водоемов Санкт-Петербурга. Антропогенное влияние на водные организмы и экосистемы: Матер. V Всерос. конф. по водной экотоксикологии, посвященной памяти Б.А. Флерова. Борок, с. 13-16 [Belyakov V.P., Sotnikov I.V. (2014) Morphological deformations of chironomid larvae as an indicator of contamination of water bodies of St. Petersburg. Anthropogenic impact on aquatic organisms and ecosystems: Mater. 5 Russian Conf. in aquatic ecotoxicology, dedicated to the memory of B. A. Flerov. Borok, p. 13-16 (in Russian)]

Винберг Г.Г., Беляцкая Ю.С. (1959) Соотношение интенсивности обмена и веса тела у пресноводных моллюсков. Зоологический журнал, 38 (8): 1164-1171 [Vinberg G.G., Belyatskaya Y.S. (1959) Dependence of the intensity of metabolism on body weight of freshwater mollusks. Journal of Zoology [Zoologicheskii zhurnal], 38 (8): 1164-1171 (in Russian)]

Водные объекты Санкт-Петербурга (2002) Кондратьев С.А., Фрумин Г.Т. (ред.) СПб., 348 c. [Water objects of St. Petersburg (2002) Kondratiev S.A., Frumin G.T. (eds.) St. Petersburg, 348 p. (in Russian)]

Голубков С.М. (2000) Функциональная экология личинок амфибиотических насекомых. Труды Зоологического института РАН, Т. 284, 288 c. [Golubkov S.M. (2000) The functional ecology of larvae of amphibiotic insects. Proceedings of the Zoological Institute RAS, Vol. 284, 288 p. (in Russian)]

Игнатьева Н.В. (2014) Гидрохимическая характеристика трех озерно-речных систем Санкт-Петербурга и Ленинградской области. Экосистемы малых рек: биоразнообразие, экология, охрана: Мат. лекиий II-й Всерос. школь-конф. Ярославль, с. 165-168 [Ignatieva N.V. (2014) Hydrochemical characteristics of the three lake-river systems of St. Petersburg and the Leningrad region. Ecosystems of small rivers: biodiversity, ecology, protection: Material of lectures at the 2-nd Russian school-conference. Yaroslavl, p. 165-168 (in Russian)]

Камлюк Л.В. (1974) Энергетический обмен у свободноживущих плоских и кольчатых червей и факторы, его определяющие. Журнал общей биологии, 35 (6): 874-885 [Kamlyuk L.V. (1974) Energy metabolism in free-living flatworms and annelids and determine factors. Biology Bulletin Reviews [Zhurnal obshchei biologii], 35 (6): 874-885 (in Russian)]

Кузьменко К.Н. (1964) Распределение и количественное развитие бентофауны в разнотипных малых озерах Карельского перешейка. Озера Карельского перешейка. Лимнология и методика исследований. Николаев И.И. (ред.) М.-Л., Наука, с. 89-100 [Kuzmenko K.N. (1964) Distribution and quantitative development of benthofauna in polytypic small lakes of the Karelian isthmus. Lakes of the Karelian isthmus. Limnology and methods. Nikolaev I.I. (ed.) Moscow-Leningrad, Nauka, p. 89-100 (in Russian)]

Курашов Е.А., Барков Д.В., Анисимов А.А. (2006) Роль байкальского вселенца Gmelinoides fasciatus (Stebbing) в формировании литоральных биоценозов о. Валаам (Ладожское озеро). Биология внутренних вод, 1: 74-84 [Kurashov E.A., Barkov D.V., Anisimov A.A. (2006) The role of baikalian invader Gmelinoides fasciatus (Stebb.) in formation of littoral biocenoses of the Valaam island (Lake Ladoga). Inland Water Biology [Biologiya vnutrennikh vod], 1: 74-84 (in Russian)]

$$
-496-
$$


Методические рекомендации по сбору и обработке материалов при гидробиологических исследованиях на пресноводных водоемах: Зообентос и его продукиия (1983) Винберг Г.Г., Лаврентьева Г.М. (ред.) Л., ГосНИОРХ, 52 с. [Methodical recommendations on collection and processing of materials in hydrobiological studies on freshwater bodies: the Zoobenthos and its production (1983) Winberg G.G., Lavrenteva G.M. (eds.) Leningrad, GosNIORH, 52 p. (in Russian)]

Назарова Л.Б. (2002) Морфологические деформации личинок комаров-звонцов (Diptera, Chironomidae) в гидробиологических исследованиях. Усnехи современной биологии, 122 (5): 505-512 [Nazarova L.B. (2002) Morphological deformation of the larvae of chironomid midges (Diptera, Chironomidae) in hydrobiological investigations. Biology Bulletin Reviews [Uspekhi sovremennoi biologii], 122 (5): 505-512 (in Russian)]

Петров В.В. (1971) Изменение продуктивности бентоса малых озер Карельского перешейка под влиянием минеральных удобрений. Автореф. дис. ... канд. биол. наук. Л., 21 с. [Petrov V.V. (1971) Change in the productivity of the benthos of small lakes of the Karelian isthmus under the influence of mineral fertilizers. Author. dis. ... candidate. Biol. Sciences. Leningrad, 21 p. (in Russian)]

Слепухина Т.Д. (1987) Зообентос как индикатор качества вод в озерах. Водные ресурсы, 5: 145-148 [Slepukhina T.D. (1987) Zoobenthos as indicator of water quality in lakes. Water Resources [Vodnie resursi], 5: 145-148 (in Russian)]

Трифонова И.С. (1979) Состав и продуктивность фитопланктона разнотипных озер Карельского перешейка. Л., Наука, 168 с. [Trifonova I.S. (1979) Composition and productivity of phytoplankton in different type lakes of the Karelian isthmus. Leningrad, Nauka, 168 p. (in Russian)]

Шитиков В.К., Розенберг Г.С., Зинченко Т.Д. (2005) Количественная гидроэкология: методы, критерии, решения. Кн. 1. М., Наука, 281 с. [Shitikov V.K., Rozenberg G.S., Zinchenko T.D. (2005) Quantitative hydroecology: methods, criteria, solutions. Book 1. Moscow, Nauka, 281 p. (in Russian)]

Яковлев В.А. (2000) Трофическая структура зообентоса как показатель состояния водных экосистем и качества воды. Водные ресурсы, 27 (2): 237-244 [Yakovlev V.A. (2000) Trophic structure of zoobenthos as an indicator of the status of aquatic ecosystems and water quality. Water Resources [Vodnie resursi], 27 (2): 237-244 (in Russian)]

Яковлев В.А. (2005) Пресноводный зообентос северной Фенноскандии (разнообразие, структура и антропогенная динамика). Ч. 1. Апатиты, Кольский научный центр РАН, 161 с. [Yakovlev V.A. (2005) Freshwater zoobenthos in the Northern Fennoscandia (diversity, structure and the anthropogenic dynamics). Part 1. Apatity, Kola science center RAS, 161 p. (in Russian)]

Johnson R.K. (1995) The indicator concept in freshwater biomonitoring. Chironomids: From genes to ecosystems. Cranston P. (ed.) Melbourne, CSIRO, p. 11-27

Jonasson P.M. (1969) Bottom fauna and eutrophication. Eutrophication: Causes, consequences, correctives. Washington, National Academy of Sciences, p. 274-305

Saether O.A. (1980) The influence of eutrophication on deep lake benthic invertebrate communities. Progress in Water Technology, 12 (2): 161-180

Sladecek V. (1973) System of water quality from the biological point of view. Archiv für Hydrobiologie. Ergebnisse der Limnologie, 7: 1-218

$$
-497-
$$


Warwick W.F. (1985) Morphological abnormalities in Chironomidae (Diptera) larvae as measures of toxic stress in freshwater ecosystems: indexing antennal deformities in Chironomus Meigen. Canadian Journal of Fisheries and Aquatic Sciences, 42 (12): 1881-1914

Wiśniewski R.J., Dusoge K. (1983) Ecological characteristics of lakes in north-eastern Poland versus their trophic gradient. IX. The macrobenthos of 44 lakes. Ekologia polska, 31 (2): 429-457 